\title{
Culture Conditions for the Preparation of Cells Containing High Tyrosine Phenol Lyase Activity ${ }^{\dagger}$
}

\author{
Hitoshi EneI, Koichi Yamashita, Shinji Okumura and Hideaki Yamada* \\ Central Research Laboratories, Ajinomoto Co., Ltd., Kawasaki \\ * Research Institute for Food Science, Kyoto University; Kyoto
}

Received June 22, 1972

\begin{abstract}
Culture conditions for the preparation of cells containing high tyrosine phenol lyase activity were studied with En winia herbicola ATCC 21434. Adding pyridoxine to the medium enhanced enzyme formation, suggesting that it was utilized as a precursor of the coenzyme, pyridoxal phosphate. Glycerol plus succinic acid; amino acids, such as, DL-methionine, DL-alanine and glycine; and metallic ion, ferrous ion promoted enzyme formation as well as cell growth. Adding L-tyrosine, as inducer, to the culture medium was essential for enzyme formation. However, when large amounts of L-tyrosine were added, the enzyme formation was repressed by the phenol liberated from L-tyrosine. In fact, formation of the enzyme was enhanced by removing phenol during cultivation. L(D)-Phenylalanine or phenylpyruvic acid had a synergistic effect on the induction of enzyme by L-tyrosine.

Cells with high enzyme activity were prepared by growing cells at $28^{\circ} \mathrm{C}$ for $28 \mathrm{hr}$ in a medium containing $0.2 \%$ L-tyrosine, $0.2 \% \mathrm{KH}_{2} \mathrm{PO}_{4}, 0.1 \% \mathrm{MgSO}_{4} \cdot 7 \mathrm{H}_{2} \mathrm{O}, 0.001 \% \mathrm{FeSO}_{4}$. $7 \mathrm{H}_{2} 0,0.01 \%$ pyridoxine $\cdot \mathrm{HCl}, 0.6 \%$ glycerol, $0.5 \%$ succinic acid, $0.1 \%$ DL-methionine, $0.2 \%$ DL-alanine, $0.05 \%$ glycine, $0.1 \% \mathrm{~L}$-phenylalanine and $120 \mathrm{ml} /$ liter hydrolyzed soybean protein in tap water with the $\mathrm{pH}$ controlled at 7.5 throughout cultivation.
\end{abstract}

Tyrosine phenol lyase is an enzyme which catalyzes the stoichiometric conversion of L-tyrosine to pyruvic acid, ammonia and phenol, and requires pyridoxal phosphate as a cofactor. $^{(1 \tau)}$ Apparently homogeneous preparations of the enzyme were prepared in our laboratory from cells of Escherichia intermedia and Erwinia herbicola grown in media supplemented with L-tyrosine. ${ }^{5,6,8}$ We reported that the crystalline preparation of the enzyme catalyzes a series of $\alpha, \beta$-elimination, $\beta$-replacement and racemization. ${ }^{9 \sim 11}$ We also showed that this enzyme catalyzes the synthesis of L-tyrosine or L-dopa from DL-serine and phenol or pyrocatechol, in significantly high yields. ${ }^{12)}$ Since intact cells were used directly as the enzyme in this synthetic reaction, it was necessary to establish culture conditions under which cells would grow well and the enzyme would be sufficiently accumulated in growing cells. The culture conditions for the preparation of cells containing high

+ Microbiological Synthesis of L-Tyrosine and 3,4-Dihydroxyphenyl-L-alanine. Part III. tyrosine phenol lyase activity are described in this paper.

\section{EXPERIMENTAL}

Chemicals. All chemicals used were commercial products. L-Dopa was purchased from Daiichi Kagaku Company, Ltd., Tokyo.

Microorganism. Erwinia herbicola ATCC 21434 was used as the enzyme source.

Intact cell preparation. Intact cells of Erwinia herbicola were prepared as follows. This organism was aerobically cultured at $27 \sim 10^{\circ} \mathrm{C}$ for $28 \mathrm{hr}$. The $500 \mathrm{ml}$ shaking flasks contained $60 \mathrm{ml}$ of basal medium, consisting of $0.2 \% \quad \mathrm{KH}_{2} \mathrm{PO}_{4}, 0.1 \% \quad \mathrm{MgSO}_{4} \cdot 7 \mathrm{H}_{2} \mathrm{O}$ supplemented with $0.2 \%$ L-tyrosine and varying amounts of organic nutrients in tap water $(\mathrm{pH} 7.5)$. In the investigation of neutralizing agents during cultivation, the organism was aerobically cultured in a 1 -liter jar fermenter with the $\mathrm{pH}$ adjusted to 7.5 with various neutralizing agents. Intact cells were obtained by centrifuging the culture broth.

Assay of enzyme activity. Intact cells were directly used as the enzyme. Tyrosine phenol lyase activity in intact cells was estimated by determining the amount 
of L-dopa synthesized from DL-serine and pyrocatechol. The standard assay mixture contained $100 \mathrm{mg}$ of pyrocatechol, $200 \mathrm{mg}$ of DL-serine, $50 \mathrm{mg}$ of ammonium acetate, $20 \mathrm{mg}$ of sodium sulfite, $10 \mathrm{mg}$ of EDTA and

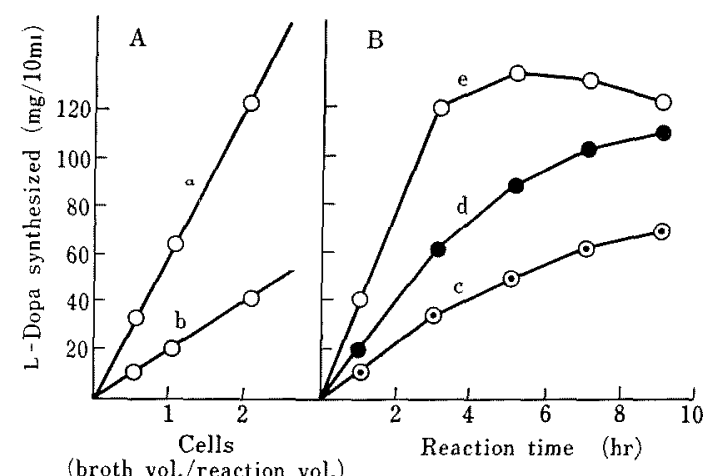

FIG, 1. L-Dopa Synthesis as a Function of Time and the Amount of Intact Cells Added.

The cells were grown at $28^{\circ} \mathrm{C}$ for $28 \mathrm{hr}$ in a medium containing $0.2 \%$ L-tyrosine, $0.2 \% \mathrm{KH}_{2} \mathrm{PO}_{4}, 0.1 \%$ $\mathrm{MgSO}_{4} \cdot 7 \mathrm{H}_{2} \mathrm{O}, 0.001 \% \mathrm{FeSO}_{4} \cdot 7 \mathrm{H}_{2} \mathrm{O}, 0.01 \%$ pyridoxine $\mathrm{HCl}, 0.6 \%$ glycerol, $0.5 \%$ succinic acid, $0.1 \%$ DL-methionine, $0.2 \%$ DL-alanine, $0.05 \%$ glycine, $0.1 \%$ L-phenylalanine and $120 \mathrm{ml} /$ liter hydrolyzed soybean protein liquor in tap water with the $\mathrm{pH}$ controlled at 7.5. In Fig. 1-A, the amount of cells is shown as ratios of the volume of the culture broth used to harvest the cells, to the volume of reaction mixture. Reaction time is $3 \mathrm{hr}$ (a) and $1 \mathrm{hr}$ (b). In Fig. 1-B, the amount of cells is $1 / 2$ (c), 1 (d) or 2 (e).

Tyrosine phenol lyase activity was determined by measuring the amount of L-dopa synthesized in the reaction mixture described in the text. intact cells harvested from $10 \mathrm{ml}$ of culture broth (approximately $100 \mathrm{mg}$ of intact cells as wet cells) in a total volume of $10 \mathrm{ml}$ ( $\mathrm{pH} 8.0$ adjusted by ammonia). This mixture was incubated at $22^{\circ} \mathrm{C}$ for $1 \sim 3 \mathrm{hr}$. As shown in Fig. 1. The synthesis of $\mathrm{L}$-dopa was practically linear for $1 \sim 3 \mathrm{hr}$ during the incubation period, and enough L-dopa was synthesized in these systems to allow determination with little error. Thus, the activity of tyrosine phenol lyase was defined as the amount of L-dopa synthesized per hour against the reaction volume by the amount of cells separated from an equivalent volume of culture broth.

Analytical methods. (1) Bacterial growth is shown, using a Hirama Electro-photocolorimeter, as the optical density at $562 \mathrm{~m} \mu$ (O.D.) of the culture broth after diluted 26 times.

(2) Determination of L-dopa was carried out as described in the previous paper. ${ }^{13}$ )

\section{RESULTS}

1. Effect of various substances added to the medium on the formation of tyrosine phenol lyase

Effects of various substances added to the basal medium on the tyrosine phenol lyase activity in intact cells were investigated.

I) Organic mutrients. Table I shows that the mixture of yeast extracts, polypeptone and meat extracts, yeast extracts and hydrolyzed soybean protein were more favorable for

Table I. Effect of Various Nutrients Added to Basal Mediuma on the Formation of Tyrosine Phenol Lyase

\begin{tabular}{lcccc} 
Organic nutrient & (conc.) & $\begin{array}{c}\text { Cultivation } \\
\text { final } \\
\text { gH }\end{array}$ & $\begin{array}{c}\text { Activity of } \\
(\text { O.D. }\end{array}$ & $\begin{array}{c}\text { L-dopa synthesis } \\
\text { (mg/10 ml/hr) }\end{array}$ \\
\hline Yeast extract & $0.5 \%$ & 8.40 & 0.085 & 1.6 \\
Polypeptone & $2.0 \%$ & 8.60 & 0.240 & 3.4 \\
Meat extract & $0.5 \%$ & 8.60 & 0.080 & 1.3 \\
Yeast extract $1.0 \%+$ & $2.0 \%$ & 8.45 & 0.110 & 1.4 \\
polypeptone $0.5 \%+$ & $0.5 \%$ & 8.60 & 0.080 & 2.0 \\
meat extract $0.5 \%$ & $2.0 \%$ & 8.80 & 0.125 & 3.7 \\
Hydrolyzed soybean & & & & 3.1 \\
protein liquor ${ }^{b 1}$ & & 8.55 & 0.230 & 3.6 \\
\hline
\end{tabular}

a) L-Tyrosine $0.2 \%$ and pyridoxine $\mathrm{HCl} 0.01 \%$ were supplemented.

b) Concentration of amino acids was $10 \%$. 
enzyme formation as well as cell growth. Due to the more promotive effect of hydrolyzed soybean protein than polypeptone, it was thought necessary to add some kinds of specific amino acids to the medium to produce this enzyme.

2) Vitamins. Supplementation with va- rious vitamins other than pyridoxine $\cdot \mathrm{HCl}$ and pyridoxal phosphate were ineffective for enzyme formation, as shown in Table II. Adding pyridoxine $\mathrm{HCl}$ to the medium enhanced enzyme formation, suggesting that it was utilized as a precursor of the coenzyme, pyridoxal phosphate.

Table II. Effect of Vitamins Added to Basal Medium ${ }^{a}$ on the Formation of Tyrosine Phenol Lyase

\begin{tabular}{|c|c|c|c|c|c|}
\hline Vitamin & (mg/liter) & $\begin{array}{l}\text { Activity } \\
\text { of L-dopa } \\
\text { synthesis. } \\
\text { (mg/10 ml/hr) }\end{array}$ & Vitamin & (mg/liter) & $\begin{array}{c}\text { Activity } \\
\text { of } \mathrm{L}-\text { dopa } \\
\text { synthesis } \\
(\mathrm{mg} / 10 \mathrm{ml} / \mathrm{hr})\end{array}$ \\
\hline None & - & 1.5 & Riboflavin & 0.5 & 1.6 \\
\hline \multirow[t]{2}{*}{ Thiamine $\cdot \mathrm{HCl}$} & 0.5 & 1.8 & & 10.0 & 1.8 \\
\hline & 10.0 & 1.7 & Ca-Pantothenate & 0.5 & 1.4 \\
\hline \multirow[t]{2}{*}{ Carotin } & 0.5 & 1.8 & & 10.0 & 1.3 \\
\hline & 10.0 & 0.3 & Pyridoxine $\cdot \mathrm{HCl}$ & 0.5 & 2.3 \\
\hline \multirow[t]{2}{*}{ Biotin } & 0.5 & 1.7 & & 10.0 & 3.2 \\
\hline & 10.0 & 1.8 & & 100.0 & 3.6 \\
\hline \multirow[t]{2}{*}{ Nicotinamide } & 0.5 & 1.6 & Pyridoxal phosphate & 0.5 & 2.0 \\
\hline & 10.0 & 1.8 & & 10.0 & 2.9 \\
\hline \multirow[t]{2}{*}{ L-Ascorbic acid } & 0.5 & 1.7 & & 100.0 & 3.5 \\
\hline & 10.0 & 1.6 & & 200.0 & 3.7 \\
\hline \multirow[t]{2}{*}{$\mathrm{B}_{12}$} & 0.5 & 1.5 & & 500.0 & 3.6 \\
\hline & 10.0 & 1.6 & & & \\
\hline
\end{tabular}

a) L-Tyrosine $0.2 \%$ and hydrolyzed liquor of soybean protein $120 \mathrm{ml} /$ liter were supplemented.

Table III. Effect of Glucose or Glycerol Added to Basal Medium ${ }^{a}$ on the formation of Tyrosine Phenol Lyase

\begin{tabular}{|c|c|c|c|c|c|c|}
\hline \multirow{2}{*}{\multicolumn{2}{|c|}{$\begin{array}{l}\text { Carbohydrate } \\
(\%)\end{array}$}} & \multirow{2}{*}{\multicolumn{2}{|c|}{$\begin{array}{l}\text { Organic acid } \\
(\%)\end{array}$}} & \multicolumn{2}{|c|}{ Cultivation } & \multirow{2}{*}{$\begin{array}{l}\text { Activity of } \\
\text { L-dopa synthesis } \\
(\mathrm{mg} / 10 \mathrm{ml} / \mathrm{hr})\end{array}$} \\
\hline & & & & $\begin{array}{l}\text { final } \\
\mathrm{pH}\end{array}$ & $\begin{array}{l}\text { growth } \\
\text { (O.D.) }\end{array}$ & \\
\hline None & & None & & 8.45 & 0.335 & 3.5 \\
\hline \multirow[t]{3}{*}{ Glucose } & 0.4 & None & & 8.30 & 0.350 & 3.2 \\
\hline & 0.6 & None & & 8.30 & 0.380 & 3.1 \\
\hline & 1.0 & None & & 8.00 & 0.475 & 2.6 \\
\hline \multirow[t]{3}{*}{ Glycerol } & 0.4 & None & & 8.35 & 0.340 & 4.0 \\
\hline & 0.6 & None & & 8.35 & 0.460 & 4.3 \\
\hline & 1.0 & None & & 8.10 & 0.570 & 2.9 \\
\hline Glucose & 0.6 & Citrate & 0.5 & 8.45 & 0.410 & 3.7 \\
\hline \multirow[t]{7}{*}{ Glycerol } & 0.6 & Citrate & 0.5 & 8.40 & 0.480 & 4.8 \\
\hline & 0.6 & Succinate & 0.5 & 8.35 & 0.405 & 5.3 \\
\hline & 0.6 & Fumarate & 0.5 & 8.35 & 0.395 & 5.5 \\
\hline & 0.6 & Maleate & 0.5 & 8.40 & 0.380 & 5.0 \\
\hline & 0.6 & Malate & 0.5 & 8.40 & 0.390 & 5.1 \\
\hline & 0.6 & $\begin{array}{l}\alpha \text {-Keto- } \\
\text { glutarate }\end{array}$ & 0.5 & 7.60 & 0.520 & 3.2 \\
\hline & 0.6 & Pyruvate & 0.5 & 8.30 & 0.480 & 3.3 \\
\hline
\end{tabular}

a) L-Tyrosine $0.2 \%$, pyridoxine $\cdot \mathrm{HCl} 0.01 \%$ and hydrolyzed soybean protein liquor $120 \mathrm{ml} /$ liter were supplemented. 
Table IV. Effect of Amino Acids Added ro

Basal Medium $^{a}$ on the Formation of Tyrosine Phenol Lyase

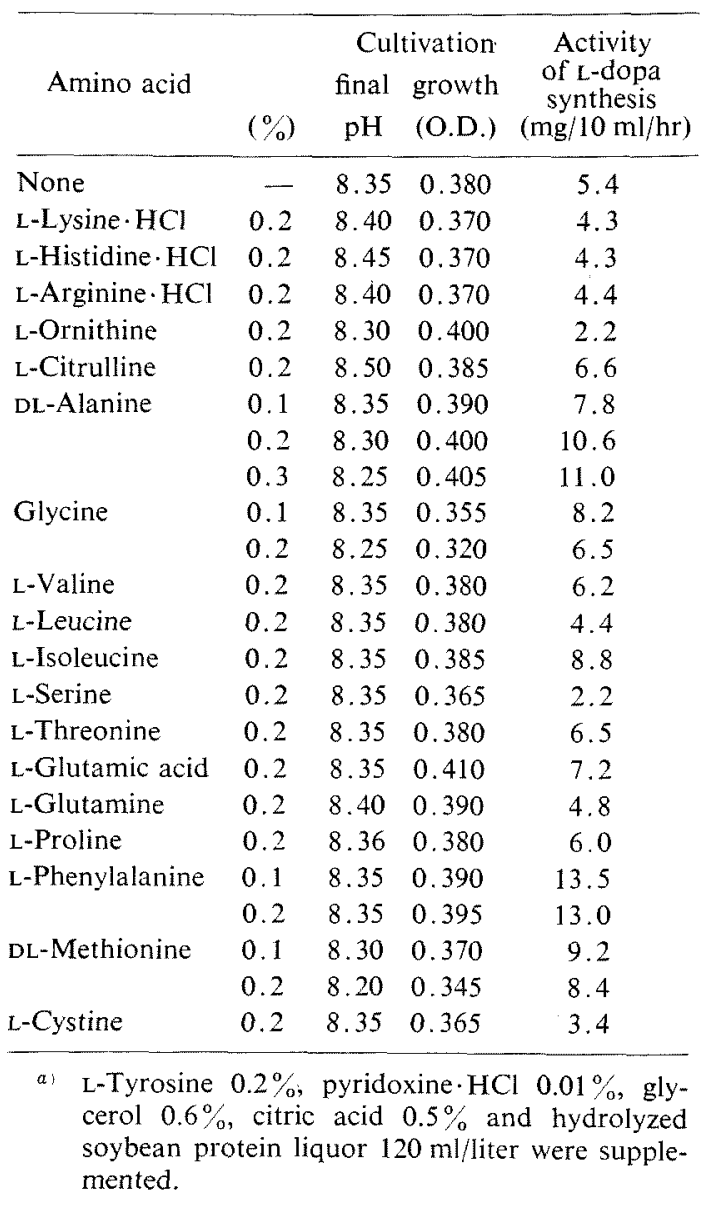

3) Carbohydrates. Glycerol was more suitable as the carbon source than glucose for
Table VI. Effect of Metal Ions Added to

Basal Medium $^{a}$ on the Formation of Tyrosine Phenol Lyase

\begin{tabular}{lccc}
\hline $\begin{array}{c}\text { Metal ion } \\
(10 \mathrm{ppm})\end{array}$ & $\begin{array}{c}\text { Cultivation } \\
\text { final } \\
\text { pH }\end{array}$ & $\begin{array}{c}\text { growth } \\
\text { (O.D. })\end{array}$ & $\begin{array}{c}\text { Activity of } \\
\text { L-dopa synthesis } \\
(\mathrm{mg} / 10 \mathrm{ml} / \mathrm{hr})\end{array}$ \\
\hline None & 8.35 & 0.340 & 37.5 \\
$\mathrm{Ca}^{2-}$ & 8.35 & 0.385 & 37.0 \\
$\mathrm{Fe}^{2+}$ & 8.35 & 0.460 & 62.5 \\
$\mathrm{Mn}^{2+}$ & 8.35 & 0.340 & 36.5 \\
$\mathrm{Ba}^{2+}$ & 8.40 & 0.385 & 37.0 \\
$\mathrm{Li}^{2-}$ & 8.25 & 0.415 & 40.5 \\
$\mathrm{Mo}^{2+}$ & 8.35 & 0.390 & 40.0 \\
$\mathrm{Ni}^{2+}$ & 8.35 & 0.365 & 34.5 \\
$\mathrm{~Pb}^{2+}$ & 8.40 & 0.375 & 32.2 \\
$\mathrm{Sn}^{2+}$ & 8.35 & 0.370 & 33.0 \\
$\mathrm{Zn}^{2+}$ & 8.35 & 0.355 & 37.0 \\
$\mathrm{Co}^{2-}$ & 8.30 & 0.370 & 36.0 \\
$\mathrm{Cu}^{2+}$ & 8.30 & 0.340 & 22.0 \\
$\mathrm{Ca}^{2+}$ & 8.35 & 0.355 & 41.0 \\
$\mathrm{Fe}^{2+}+\mathrm{Zn}^{2+}$ & 8.40 & 0.450 & 65.5 \\
$\mathrm{Fe}^{2+}+\mathrm{Mn}^{2+}$ & 8.40 & 0.440 & 60.5 \\
$\mathrm{Fe}^{2+-}+\mathrm{Zn}^{2-}+\mathrm{Mn}^{2+}$ & 8.45 & 0.435 & 63.5 \\
\hline
\end{tabular}

a L-Tyrosine $0.2 \%$, pyridoxine $\cdot \mathrm{HCl} 0.01 \%$, glycerol $0.6 \%$, succinic acid $0.5 \%$, hydrolyzed soybean protein liquor $120 \mathrm{ml} /$ liter, DL-ala $0.2 \%$, gly $0.05 \%$, DL-met $0.1 \%$ and L-phe $0.1 \%$ were supplemented.

cell growth and for accumulating this enzyme in growing cells, as seen in Table III. The optimum concentration of glycerol was $6 \mathrm{~g} / \mathrm{liter}$, and adding more than $10 \mathrm{~g} /$ liter of glycerol repressed enzyme formation. Enzyme formation was also promoted by adding glycerol together with an organic acid (succinic acid, citric acid, fumaric acid, malic acid or maleic

Table V. Effect of Amino Acids Added to Basal Medium ${ }^{2}$. on the Formation of Tyrosine Phenol Lyase

\begin{tabular}{|c|c|c|c|c|c|c|c|}
\hline \multirow[b]{2}{*}{$\begin{array}{c}\text { DL-Ala } \\
(\%)\end{array}$} & \multirow[b]{2}{*}{$\begin{array}{l}\text { Gly } \\
(\%)\end{array}$} & \multirow[b]{2}{*}{$\begin{array}{c}\text { DL-Met } \\
(\%)\end{array}$} & \multirow[b]{2}{*}{$\begin{array}{c}\text { L-Phe } \\
(\%)\end{array}$} & \multirow[b]{2}{*}{$\begin{array}{c}\text { L-Ileu } \\
(\%)\end{array}$} & \multicolumn{2}{|c|}{ Cultivation } & \multirow{2}{*}{$\begin{array}{c}\text { Activity } \\
\text { of } \mathrm{L} \text {-dopa } \\
\text { synthesis } \\
(\mathrm{mg} / 10 \mathrm{~m}] / \mathrm{hr})\end{array}$} \\
\hline & & & & & $\begin{array}{c}\text { final } \\
\mathrm{pH}\end{array}$ & $\begin{array}{l}\text { growth } \\
\text { (O.D.) }\end{array}$ & \\
\hline- & - & - & - & - & 8.35 & 0.385 & 5.4 \\
\hline 0.2 & 0.05 & - & - & - & 8.20 & 0.380 & 16.5 \\
\hline 0.2 & 0.05 & 0.1 & - & - & 8.30 & 0.360 & 20.8 \\
\hline 0.2 & 0.05 & - & 0.1 & - & 8.35 & 0.390 & 26.6 \\
\hline 0.2 & 0.05 & - & - & 0.2 & 8.35 & 0.385 & 17.8 \\
\hline 0.2 & 0.05 & 0.1 & 0.1 & - & 8.30 & 0.380 & 38.0 \\
\hline 0.2 & 0.05 & 0.1 & 0.1 & 0.2 & 8.35 & 0.390 & 36.6 \\
\hline
\end{tabular}

a) L-Tyrosine $0.2 \%$, pyridoxine $\mathrm{HCl} 0.01 \%$, glycerol $0.6 \%$, succinic acid $0.5 \%$ and hydrolyzed soybean protein liquor $120 \mathrm{ml} /$ liter were supplemented. 
acid), except for $\alpha$-keto organic acids (pyruvic acid or $\alpha$-ketoglutaric acid).

4) Amino acids. Effect of various amino acids on enzyme formation were investigated. As shown in Table IV, DL-alanine, L-phenylalanine, DL-methionine, L-isoleucine and glycine remarkably increased enzyme synthesis. However, the addition of L-serine, L-ornithine. $\mathrm{HCl}$ or L-cystine inhibited enzyme synthesis. Moreover, when mixtures containing these effective amino acids were added to the medium, enzyme production was remarkably increased as seen in Table V.

5) Metal ions. Of the metal ions listed in Table VI, $\mathrm{Fe}^{2+}$ ion was the only one effective for enzyme formation. $\mathrm{Fe}^{2+}$ ion was also more favorable for cell growth than were the other ions.

2. Effect of inducer on the formation of tyrosine phenol lyase

Since tyrosine phenol lyase is considered to be a tyrosine-inducible enzyme, ${ }^{1,2}$ adding L-tyrosine, as inducer, to the culture media was essential for enzyme formation. Effects of tyrosine or its analogues on the synthesis of tyrosine phenol lyase and effects of synergistic materials on the induction of this enzyme by tyrosine were investigated.

1) Effect of L-tyrosine concentration. Table VII shows that the maximum formation of enzyme occurred in cells grown in the pre-
TABle VII. EFFect of L-Tyrosine ConcentRation Added to Basal Medrum ${ }^{a}$ on the Formation of Tyrosine Phenol Lyase

\begin{tabular}{cccc}
$\begin{array}{c}\text { L-Tyrosine } \\
(\%)\end{array}$ & $\begin{array}{c}\text { Cultivation } \\
\text { final } \\
\text { pH }\end{array}$ & $\begin{array}{c}\text { growth } \\
\text { (O.D. })\end{array}$ & $\begin{array}{c}\text { Activity of } \\
\text { L-dopa } \\
\text { synthesis } \\
(\mathrm{mg} / 10 \mathrm{ml} / \mathrm{hr})\end{array}$ \\
\hline- & 8.50 & 0.350 & 0.1 \\
0.05 & 8.45 & 0.330 & 1.2 \\
0.10 & 8.45 & 0.315 & 2.6 \\
0.20 & 8.45 & 0.310 & 3.7 \\
0.30 & 8.35 & 0.270 & 2.4 \\
0.50 & 8.00 & 0.220 & 1.8 \\
\hline
\end{tabular}

a) Pyridoxine $\mathrm{HCl} 0.01 \%$ and hydrolyzed soybean protein liquor $120 \mathrm{ml} /$ liter were supplemented.

sence of $0.2 \%$ L-tyrosine. When large amounts of L-tyrosine were added, inhibition of enzyme formation and repression of cell growth were observed. This phenomenon seemed to be caused by phenol liberated from L-tyrosine added as inducer. The phenol, added to the medium containing $0.2 \% \mathrm{~L}-$ tyrosine, repressed enzyme formation and cell growth. The addition of resin (Amberlite IR-45, OH-form), in the presence of $0.4 \%$ of L-tyrosine or $0.2 \%$ of L-tyrosine together with $0.2 \%$ phenol, derepressed enzyme formation and cell growth, as shown in Table VIII.

2) Tyrosine analogues as inducer. Various analogues of L-tyrosine were investigated to obtain an inducer which was not decomposable during cultivation, similar to $\beta$-Dthiogalactoside used as the inducer of $\beta$ galactosidase. ${ }^{14)}$ of the various analogues,

Table Vili. Effect of l-Tyrosine, Phenol and Amberlite IR-45 Added to Basal Medum ${ }^{a l}$ on the formation of Tyrosine Phenol Lyase

\begin{tabular}{cccccc}
$\begin{array}{c}\text { L-Tyrosine } \\
(\mathrm{g} / \mathrm{dl})\end{array}$ & $\begin{array}{c}\text { Phenol } \\
(\mathrm{g} / \mathrm{dl})\end{array}$ & $\begin{array}{c}\text { Amberlite } \\
\text { IR-45 OH-form } \\
(\mathrm{g} / \mathrm{dl})\end{array}$ & $\begin{array}{c}\text { Cultivation } \\
\text { final } \\
\mathrm{pH}\end{array}$ & $\begin{array}{c}\text { growth } \\
(\mathrm{O} . \mathrm{D})\end{array}$ & $\begin{array}{c}\text { Activity of } \\
\text { L-dopa synthesis } \\
(\mathrm{mg} / 10 \mathrm{ml} / \mathrm{hr})\end{array}$ \\
\hline 0.2 & - & - & 8.35 & 0.460 & 63.0 \\
0.4 & - & - & 8.05 & 0.345 & 35.5 \\
0.2 & 0.2 & - & 8.00 & 0.320 & 31.0 \\
0.4 & - & 5.0 & 8.40 & 0.450 & 72.0 \\
0.2 & 0.2 & 5.0 & 8.30 & 0.420 & 60.0 \\
\hline
\end{tabular}

a) Pyridoxine $\cdot \mathrm{HCl} 0.01 \%$, glycerol $0.6 \%$, succinic acid $0.5 \%$, hydrolyzed soybean protein liquor $120 \mathrm{ml} / \mathrm{liter}$, DL-ala $0.2 \%$, gly $0.05 \%$, DL-met $0.1 \%$ and L-phe $0.1 \%$ were supplemented. 
$p$ - methoxy - L - phenylalanine, 3,4-dimethoxyL-phenylalanine and $m$-fluoro-DL-phenylalanine also induced tyrosine phenol lyase, at lower activity than L-tyrosine, as seen in Table IX.

Table IX. Effect of Tyrosine Derivatives AdDed to BASAL MediUm ${ }^{a}$ AS THE INDUCER ON THE FORMATION OF Trrosine Phenol Lyase

\begin{tabular}{|c|c|c|c|}
\hline \multirow{2}{*}{$\begin{array}{c}\text { Tyrosine } \\
\text { derivative } \\
\text { (conc. } 0.2 \% \text { ) }\end{array}$} & \multicolumn{2}{|c|}{ Cultivation } & \multirow{2}{*}{$\begin{array}{c}\text { Activity of } \\
\text { L-dopa } \\
\text { synthesis } \\
(\mathrm{mg} / 10 \mathrm{ml} / \mathrm{hr})\end{array}$} \\
\hline & $\begin{array}{l}\text { final } \\
\mathrm{pH}\end{array}$ & $\begin{array}{l}\text { growth } \\
\text { (O.D.) }\end{array}$ & \\
\hline L-Tyrosine & 8.35 & 0.240 & 11.9 \\
\hline D-Tyrosine & 8.35 & 0.220 & 10.5 \\
\hline Tyramine & 8.20 & 0.145 & 2.0 \\
\hline $\begin{array}{l}p \text {-Hydroxy-L- } \\
\text { phenylglycine }\end{array}$ & 8.30 & 0.190 & 2.0 \\
\hline $\begin{array}{l}p \text {-Methoxy-L- } \\
\text { phenylalanine }\end{array}$ & 8.30 & 0.195 & 5.3 \\
\hline $\begin{array}{l}p \text {-Methoxy-L- } \\
\text { phenylglycine }\end{array}$ & 8.30 & 0.185 & 1.7 \\
\hline $\begin{array}{l}p \text {-Hydroxy- } \\
\text { cinnamic acid }\end{array}$ & 8.25 & 0.285 & 3.5 \\
\hline L-Dopa & 8.10 & 0.360 & 3.3 \\
\hline $\begin{array}{l}\text { 3,4-Dimethoxy- } \\
\text { L-phenylalanine }\end{array}$ & 8.40 & 0.280 & 5.8 \\
\hline L-Phenylalanine & 8.35 & 0.300 & 3.8 \\
\hline D-Phenylalanine & 8.40 & 0.280 & 2.5 \\
\hline Phenylpyruvic acid & 8.40 & 0.320 & 3.5 \\
\hline L-Phenylglycine & 8.30 & 0.280 & 2.6 \\
\hline Cinnamic acid & 7.50 & 0.000 & 0.0 \\
\hline $\begin{array}{l}m \text {-Fluoro-L- } \\
\text { phenylalanine }\end{array}$ & 8.30 & 0.290 & 6.2 \\
\hline
\end{tabular}

a) Glycerol $0.6 \%$, succinic acid $0.5 \%, \mathrm{Fe}^{2+} 2 \mathrm{ppm}$, $\mathrm{Zn}^{2+} 2 \mathrm{ppm}$, pyridoxine $\cdot \mathrm{HCl} 0.01 \%$, DL-met $0.10 \%$, L-asp $0.07 \%$, L-thr $0.07 \%$ gly $0.3 \%$, DL-ala $1.0 \%$, L-val $0.13 \%$ and L-ileu $0.3 \%$ were supplemented.

D-Tyrosine induced this enzyme to the same degree as L-tyrosine. D-Tyrosine was reported to be degraded to phenol, pyruvate and ammonia, as was L-tyrosine, in the $\alpha, \beta$-elimination reaction of this enzyme, as described previously. ${ }^{6}$ No inducer, which is nondecomposable during cultivation, was found among the various tyrosine analogues.

3) Synergistic materials and the induction of tyrosine phenol lyase with L-tyrosine. The synergistic effect of various tyrosine analogues on the induction of tyrosine phenol lyase with L-tyrosine was studied. L-Phenylalanine, D-phenylalanine and phenylpyruvate did not induce this enzyme by themselves (Table IX), but these materials gave efficient synergistic effects on the induction of this enzyme with L-tyrosine, as shown in Table $\mathrm{X}$.

TAble X. EFfect of Synergistic Materials

AdDed to Basal Medium ${ }^{a)}$ on the Induction of Tyrosine Phenol Lyase by L-Tyrosine

\begin{tabular}{lccc}
\hline $\begin{array}{c}\text { Tyrosine } \\
\text { analogue } \\
\text { (conc. 0.1\%) }\end{array}$ & $\begin{array}{c}\text { Cultivation } \\
\text { final }\end{array}$ & $\begin{array}{c}\text { growth } \\
\text { (O.D.) }\end{array}$ & $\begin{array}{c}\text { Activity } \\
\text { of L-dopa } \\
\text { synthesis } \\
\text { (mg/10 ml/hr) }\end{array}$ \\
\hline- & 8.35 & 0.250 & 12.5 \\
$\begin{array}{l}\text { L-Phenylalanine } \\
\text { D-Phenylalanine }\end{array}$ & 8.30 & 0.390 & 62.5 \\
$\begin{array}{l}\text { Phenylpyruvic } \\
\text { acid }\end{array}$ & 8.40 & 0.320 & 60.0 \\
$\begin{array}{l}\text { D-Tyrosine } \\
\begin{array}{l}\text { L-Phenylglycine } \\
m \text {-Fluoro-L- }\end{array}\end{array}$ & 8.05 & 0.220 & 8.0 \\
phenylalanine & 8.30 & 0.210 & 9.5 \\
$\begin{array}{l}\text { p-Methoxy-L- } \\
\text { phenylalanine }\end{array}$ & 8.25 & 0.230 & 10.0 \\
\end{tabular}

a) L-Tyrosine $0.2 \%$, glycerol $0.6 \%$, succinic acid $0.5 \%, \mathrm{Fe}^{2+} 2 \mathrm{ppm}, \mathrm{Zn}^{2+} 2 \mathrm{ppm}$, pyridoxine $\cdot \mathrm{HCl}$ $0.01 \%$, DL-met $0.1 \%$, L-asp $0.07 \%$, L-thr $0.07 \%$, L-glu $0.6 \%$, gly $0.3 \%$, DL-ala $1.0 \%$, L-val $0.13 \%$ and L-ileu $0.3 \%$ were supplemented.

3. Culture conditions for the formation of tyrosine phenol lyase

1) Effect of aeration during cultivation on the formation of tyrosine phenol lyase. To determine the relation between aeration and the formation of tyrosine phenol lyase, cultivation was carried out by varying the volume of the culture medium in $500-\mathrm{ml}$ shaking flasks. Figure 2 shows that the optimum volume of the culture medium for the formation of tyrosine phenol lyase was $40 \sim 60 \mathrm{ml}$ in a $500-\mathrm{ml}$ shaking flask, but cell growth was somewhat repressed in this range.

2) Effect of $p H$ control of the culture medium during cultivation on the formation of tyrosine phenol lyase. The effect of controlling the $\mathrm{pH}$ of the culture medium during cultivation on the formation of tyrosine phenol lyase was investigated by using $3 \mathrm{~N}$ 


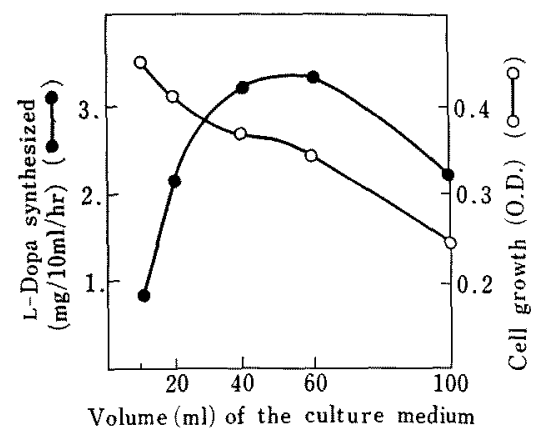

Fig. 2. Effect of Aeration on Cell Growth and on Tyrosine Phenol Lyase Formation.

Cultivation was carried out at $31^{\circ} \mathrm{C}$ for $24 \mathrm{hr}$ with varied volumes of culture medium in $500 \mathrm{ml}$ shaking flasks. The medium consisted of $0.2 \%$ L-tyrosine, $1.0 \%$ yeast extract, $0.5 \%$ polypeptone, $0.5 \%$ meat extract, $0.2 \% \mathrm{KH}_{2} \mathrm{PO}_{4}$ and $0.1 \% \mathrm{MgSO}_{4} \cdot 7 \mathrm{H}_{2} \mathrm{O}$ in a tap water ( $\mathrm{pH} 7.5)$.

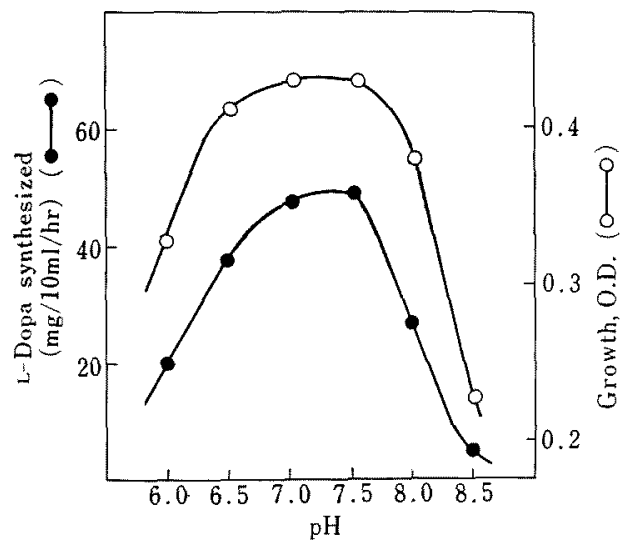

FIG. 3. Effect of $\mathrm{pH}$ of the Culture Medium on the Formation of Tyrosine Phenol Lyase.

Cultivation was carried out at $31^{\circ} \mathrm{C}$ for $28 \mathrm{hr}$ in a 2-liter jar fermenter containing 1 liter of the medium described in Fig. 1. The $\mathrm{pH}$ of the culture medium was controlled as indicated with $3 \mathrm{~N} \mathrm{KOH}$ and $10 \%$ acetic acid.

$\mathrm{KOH}$ and $10 \%$ acetic acid as neutralizing agents. (Fig. 3) As neutralizing agent, a $\mathrm{KOH}$ solution was more suitable than $\mathrm{NaOH}$ or $\mathrm{NH}_{4} \mathrm{OH}$ solutions.

3) Effect of temperature on the formation of tyrosine phenol lyase. The effect of temperature on the formation of tyrosine phenol lyase during cultivation was investigated by culturing at various temperatures for $28 \mathrm{hr}$ in 2-liter jar fermenters. Maximum enzyme formation was obtained by cultivation at $27^{\circ} \mathrm{C}$ for $28 \mathrm{hr}$. Cultivation at $34^{\circ} \mathrm{C}$ decreased the activity for L-dopa formation. The optimal temperature range for the growth of this microorganism was $27 \sim 31^{\circ} \mathrm{C}$, the same as in enzyme formation. (Fig. 4)

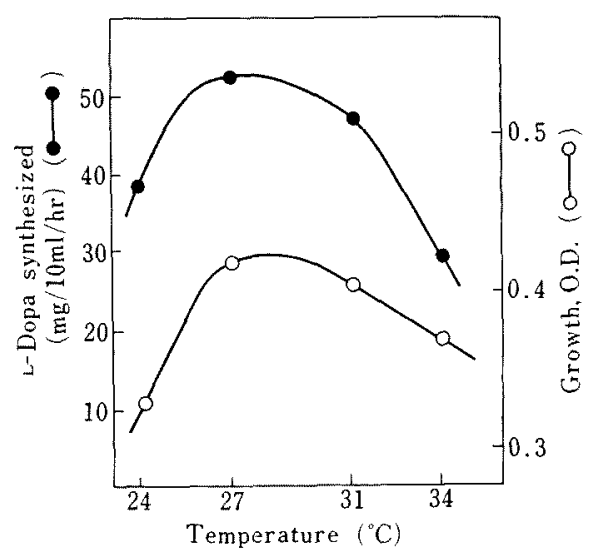

FIG. 4. Effect of Temperature during Cultivation on the Formation of Tyrosine Phenol Lyase.

Cultivation was carried out at the temperature as indicated, for $28 \mathrm{hr}$ in a 2-liter jar fermenter containing 1 liter of the medium described in Fig. 1, with the $\mathrm{pH}$ controlled at 7.5 .

\section{DISCUSSION}

Since intact cells were directly used as enzyme in this synthetic reaction, it was considered necessary to establish culture conditions under which cells grew well and enzyme was sufficiently accumulated in the cells.

Adding pyridoxine to the media promoted enzyme formation. This effect suggested that pyridoxine was utilized as the precursor of the coenzyme, pyridoxal phosphate. Glycerol plus succinic acid; amino acids, such as DL-methionine, DL-alanine and glycine; and metallic ion, ferrous ion promoted enzyme formation as well as cell growth.

Glucose or glycerol plus pyruvate causes a transient catabolic repression, but does not cause permanent catabolic repression in the induction of inducible enzyme, i.e. as with tryptophanase. ${ }^{15,16)}$ It has also been reported that catabolic repression did not occur when glycerol was used as the only carbon source. ${ }^{15}$ 
Therefore, glycerol is considered a good carbon for promoting cell growth and accumulating this enzyme. Glycerol was actually more suitable as the carbon source to promote cell growth and to accumulate this enzyme in growing cells, when $0.6 \%$ was added to the media. When a concentration of glycerol above $1.0 \%$ was added to the media, the repression of enzyme formation was observed. This repression seems to be a catabolic caused by large amounts of glycerol.

Adding L-tyrosine to the culture media as inducer was essential for the formation of enzyme. When large amounts of L-tyrosine were added, however, repression of enzyme formation was caused by phenol liberated from the L-tyrosine. Actually, enzyme formation was enhanced by removal of phenol during culture; by adding resin (Amberlite IR-45 $\mathrm{OH}$-form) to the media. Therefore, various analogues of L-tyrosine were investigated to obtain an inducer which was not decomposable during cultivation; similar to $\beta$-D-thiogalactoside, the inducer of $\beta$-galactosidase. However, no non-decomposable inducer was found among the various tyrosine analogues. L(D)-Phenylalanine and phenylpyruvic acid could not induce this enzyme by themselves, but had synergistic effects on enzyme induction with L-tyrosine when added to media containing L-tyrosine. This repression by phenol and the synergistic effect with L(D)phenylalanine or phenylpyruvic acid are very interesting phenomenon in the mechanism of induction, and will be investigated in detail.

Thus, microbial cells with high enzyme activity can be prepared by growing them at $27^{\circ} \mathrm{C}$ for $28 \mathrm{hr}$ in a medium containing $0.2 \%$ L-tyrosine, $0.2 \% \quad \mathrm{KH}_{2} \mathrm{PO}_{4}, 0.1 \% \quad \mathrm{MgSO}_{4}$. $7 \mathrm{H}_{2} \mathrm{O}, 0.01 \%$ pyridoxine $\cdot \mathrm{HCl}, 0.6 \%$ glycerol, $0.5 \%$ succinic acid, $0.2 \%$ DL-alanine, $0.05 \%$ glycine, $0.1 \%$ DL-methionine, $0.1 \%$ L-phenyl- alanine and $120 \mathrm{ml} /$ liter of hydrolyzed soybean protein in tap water, with $\mathrm{pH}$ controlled at 7.5 during cultivation.

Acknowledgement. We wish to thank Prof. $\mathrm{K}$. Ogata, Kyoto University, Kyoto, and Mr. K. Akino, Dr. T. Tsunoda and Dr. M. Takahashi, Central Research Laboratories, Ajinomoto Co., Inc., Kawasaki, for their interest and advice during the course of this work.

\section{REFERENCES}

1) Y. Kakihara and K. Ichihara, Med. J. Osaka Univ. (Osaka), 3, 497 (1953).

2) M. Uchida, Y. Taketomo, Y. Kakihara and K. Ichihara, ibid., 3, 509 (1953).

3) H. Yoshimatsu, ibid., 9, 727 (1957).

4) N. Brot, Z. Smit and H. Weissbach, Arch. Biochem. Biophys., 112, 1 (1965).

5) H. Yamada, H. Kumagai, H. Matsui, H. Ohgishi and K. Ogata, Biochem. Biophys. Res. Commun., 33, 10 (1968).

6) H. Kumagai, H. Yamada, H. Matsui, H. Ohgishi and K. Ogata, J. Biol. Chem., 245, 1767 (1970).

7) H. Kumagai, H. Yamada, H. Matsui, H. Ohgishi and K. Ogata, ibid., 245, 1773 (1970).

8) H. Kumagai, N. Kashima, H. Torii, H. Yamada, H. Enei and S. Okumura, Agr. Biol. Chem., 36, 472 (1972).

9) H. Kumagai, H. Matsui, H. Ohgishi, K. Ogata, H. Yamada, T. Ueno and H. Fukami, Biochem. Biophys. Res. Commun., 34, 266 (1969).

10) T. Ueno, H. Fukami, H. Ohgishi, H. Kumagai and H. Yamada, Biochem. Biophys. Acta, 206, 476 (1970).

11) H. Kumagai, N. Kashima and H. Yamada, Biochem. Biophys. Res. Commun., 39, 796 (1970).

12) H. Enei, H. Matsui, S. Okumura and H. Yamada, ibid., 43, 1345 (1971).

13) H. Enei, H. Matsui, K. Yamashita, S. Okumura and H. Yamada, Agr. Biol. Chem., in press.

14) J. Monod, M. Cohn, Adv. in Enzymol., 13, 67 (1952).

15) T. Sato, K. Aida and T. Uemura, J. Gen. Appl. Microbiol, 15, 109 (1969).

16) T. Sato, K. Aida and T. Uemura, ibid., 16, 361 (1970). 